\title{
Weldability problems of the technical AW7020 alloy
}

Marzena Podrez-Radziszewska, PhD., Eng.

Institute of Materials Science and Applied Mechanics, Wroclaw University of Technology, Smoluchowskiego 25, 50-372

Wroclaw, Poland:

marzena.podrez-radziszewska@pwr.wroc.pl

The article presents problems related to welding alloys of the 7000 series at an example of the AW 7020 grade alloy, by relating the obtained properties to their microstructure. Welded joints were performed with use of the weld metals according to the PN-EN ISO 18273:2007 Standard. The welded joints were subjected to evaluation of their modifiability by heat treatment.

Keywords: aluminium alloys, 7000 series, AW7020, weldability, microstructure

\section{Acknowledgements}

The work co-financed from means of the Development Project No 03003906

\section{References}

[1] MA, T, DEN OUDEN, G. (1998). Softening behaviour of Al-Zn-Mg alloys due to welding. Materials Science and Engineering A, Vol. A226, pp. 198 - 204.

[2] LECH-GREGA, M., HAWRYLKIEWICZ, S., RICHERT, M., SZYMANSKI, W. (2001). Structural parameters of 7020 alloy after heat treatment simulating the welding process. Materials Characterization, Vol. 46, pp. 251-257.

[3] TEMMAR, M., HADJI, M., SAHRAOUI, T. (2011). Effect of post-weld aging treatment on mechanical properties of Tungsten Inert Gas welded low thickness 7075 aluminium alloy joints. Materials and Design, Vol. 32, pp. 3532-3536.

[4] HWAN, T.K., SOO, W.N. (1995). Solidification cracking susceptibility of high strength aluminium alloy weldment. Scripta Materialia, Vol. 34, No. 7, pp. 1139-1145.

[5] JANAKI RAM, G.D., MITRA, T.K., SHANKAR, V., SUNDARESAN, S. (2003). Microstructural refinement through inoculation of type $702 \mathrm{Al}-\mathrm{Zn}-\mathrm{Mg}$ alloy welds and its effect on hot cracking and tensile properties. Journal of Materials Processing Technology, Vol. 142, pp. 174-181.

[6] JHA, A.K., MURTY, S.V.S.N., DIWAKAR, V., SREE Kumar, K. (2002). Metallurgical analysis of cracking in weldment of propellant tank. Engineering Failure Analysis, Vol. 10, pp. 265-273.

[7] JHA, A.K., NAGA SHIRESHA, G., SREEKUMAR, K., MITTAL, M.C., NINAN, K.N. (2007). Stress corrosion cracking in aluminium alloy AFNOR 7020-T6 water tank adaptor for liquid propulsion system. Engineering Failure Analysis, Vol. 15, pp. 787-795.

[8] GÜR, C.H., YILDIZ, I. (2004). Non-destructive investigation on the effect of precipitation hardening on impact toughness of 7020 Al-Zn-Mg alloy. Materials Science and Engineering A, Vol. A382, pp. 395-400.

[9] JHA, A.K., SREEKUMAR, K., SINHA, P.P. (2010). Cracking of aluminium alloy valve body used in attitude control of satellite launch vehicle - A metallurgical investigation. Engineering Failure Analysis, Vol. 17, pp. 1051-1061.

[10] LIM, S.G., JUNG, Y.S., KIM, S.S. (2000). Characteristics of rapidly solidified Al 7075-xwt.\% Mn alloys. Scripta Materialia, Vol. 43, pp. 1077-1081.

[11] LI, J.F., ZHENG, Z.Q., LI, S.C., CHEN, W.J., REN, W.D., ZHAO, X.S. (2007). Simulation study on function mechanism of some precipitates in localized corrosion of Al alloys. Corrosion Science, Vol. 49, pp. 2436-2449.

[12] LIU, C., NORTHWOOD, D.O., BHOLE, S.D. (2004). Tensile fracture behaviour in CO2 laser beam welds of 7075-T6 aluminium alloy. Materials and Design, Vol. 25, pp. 573-577. 